DOI: $10.21449 /$ ijate.408957

\title{
The Effects of Dynamic Criteria Mapping Assessment on Students' Conceptions and Writing Skills Development
}

\author{
Amare Tesfie Birhan (D) 1
}

${ }^{1}$ English Language and Literature, Bahir Dar Institute of Technology, Bahir Dar University, Ethiopia

\begin{abstract}
Learner center assessment procedure and application is very crucial for students writing skills improvement. Hence, this study aimed to explore the effects of dynamic criteria mapping assessment on students' conceptions and writing skills development with reference to Vygotsky, zone of proximity development. To examine the issues, time series, quasi experimental research design was employed. The major data gathering tools were pre and post-tests, questionnaire and focus group discussion. Multistage sampling technique was employed to choose the sample of the study, and 63 first year software engineering students were the subjects of the study. Among these participants, 32 students were assigned to experimental group and the other 31 students' were assigned to control group. The findings indicated that dynamic criteria mapping assessment was effective in improving students writing skills development; students were able to construct sentence with better text structure and arguments. Furthermore, they used various cohesive devices, appropriate punctuation marks and dictions in their writing. Moreover, the assessment techniques had changed their conceptions on learning writing skills and engagment in writing assessment. Generally, the researcher learned that dynamic criteria mapping assessment strategy was vital to enhance students writing skills and conceptions on learning writing skills. Lastly, it is recommended that teachers should prepare various and dynamic criteria with their respective students while they assess their students writing skills, and teachers should not use judgmental assessment techniques.
\end{abstract}

\section{ARTICLE HISTORY}

Received: 05 January 2018

Revised: 01 March 2018

Accepted: 04 March 2018

\section{KEYWORDS}

Dynamic criteria mapping assessment,

Writing skill,

Conception,

Zone of proximity

development

\section{INTRODUCTION}

It is known that assessment is vital for educational process; it is also significant to follow learners' progress of learning, to make educational decisions, to determine the effectiveness of teaching and learning and to assess the strength and the weakness of a specific instruction (Angelo \& Cross, 1993; CERI, 2008; Hyland, 2003). Accordingly, students' language skills and communicative competence have been assessed through various approaches. Researchers such as Isavi, (2012) and Hamp-Lyon (2015) mentioned that the history of foreign language assessment has been characterized by long, traditional and standardized tests, and it was judgmental, learner excluded and lacking support during assessment. Particularly, according to Breland (1983, p. 1), "writing has been assessed through direct way: samples of an examinee's

CONTACT: Amare Tesfie $\$ amaretesfie@gmail.com Institute of Technology, Bahir Dar University, Ethiopia 
writing are obtained under controlled condition and evaluated, or indirect way, students writing was assessed through grammar and sentences structure by multiple choices."

Recently, this judgmental and traditional assessments have been changed into learning oriented assessment; learners participate in every assessment procedures. The traditional assessment that dominated the late 1970s and 1980s are no longer meaningful (Fulcher \& Davidson, 2007). Fulcher and Davidson (2007) recommended tasks that mirrored language use in the real world should be used in communicative language that reflect the actual purposes of communication in clear defined contexts. Accordingly, Hailay (2017) also asserted using traditional assessment in the writing assessment is no longer sufficient.

This brings a shift of paradigm into participatory, learning oriented assessment and continuous interaction between learners and teachers. With the growing awareness that assessment is more internal to the classroom and can serve as a bridge that connects teaching to further learning, learning-oriented assessment has recently started to receive attention (Colby- kelly \& Turner, 2007; Turner, 2012; Purpura \& Turner's 2014 as cited in Kim \& Kim, 2017).

Furthermore, Whit's 2009 study (as cited in Crusan, Plakans \& Gebril, 2016) stated that, assessment remains as major element of any writing classroom instruction, and with the argument that assessment is not simply assigning grades for learners (Hyland, 2003), students have to participate in every procedure to develop their require skills.

According to Ethiopian Ministry of Education (2013), in Ethiopian higher institutions, writing courses are given for all undergraduate students to enable them to use the target skill in their academic, general and professional purposes. Particularly, courses like basic writing skills, intermediate writing skills, advanced writing skills, technical and research report writing and senior essay courses are given for content area and English major students, but students writing skills are being assessed traditionally with holistic approach or static techniques.

These frustrate students to engage in writing skill activities and to be a good writer with the target language. Aghaebrahimian, Rahimirad, Ahmadi \& Alamdari (2014) argued that oneshot test administration has always been a challenge for learners by increasing their stress.

In addition, researchers mentioned the assessment technique which does not consider context, learners' language ability and course objectives fail to include essential elements of writing. Moreover, Broad (2003, p.9) stated "writing which is assessed through rubrics made writing less capricious." Xiaoxiao and Yan (2010) also added that writing is a complicated activity, containing abilities, such as choosing suitable topics according to target audience, generating logical and clear ideas, structuring rich and proper content, demonstrating accurate language expressions.

Thus, it seemed that it is very difficult to assess and judge students writing through conventional or static approach. Evaluating students' work is more complex than static rubrics (Broad, 2003). Since static rubrics are used only to secure inter-rater reliability (Beason, 2005; Rezaei \& Lovorn, 2010; Janssen, Meier \& Trace, 2015), it may not be appropriate for students who have little exposure to use and practice writing skills.

Moreover, it is also believed that feedbacks which are employed in writing classes are an integral part of assessment and helps learners to improve learners writing skills and to minimize errors (Grami, 2005; Tekle, Endalfer \& Ebabu, 2012), but researchers such as Yiheyis \& Getachew (2014), investigated that the assessment techniques which supposed to implement in higher institutions to maximize students engagement in writing skills were not effective. Yiheyis \& Getachew added that teachers provide more of the quantitative feedback, and self and peer assessment were poorly utilized. Amare (2017) also proved that self, peer and teacher feedbacks are practiced rarely in EFL context. These and other factors contributed to students' 
difficulty in learning writing skills as a foreign and second language context (Richards, 1990; Kim \& Kim, 2005).

These may affect students' conceptions on learning writing skills. As Temesgen (2013) investigated EFL students have wrong perception on writing skills. Moreover, the researcher experience revealed that students had low level of self-efficacy on writing skills. They perceived writing is one of the most difficult skills which they could not improve.

These conceptions might be based on lack of writing skills exposure, teaching and learning methodology and assessment techniques. According to (Freeman \& Richards, 1993; Mclean, 2001) students develop a conception about their education, language background, schooling, exposure about learning and assessment. Furthermore, teachers understanding about teaching and assessing writing also affects students' perceptions (Endalfer, Ebabu \& Tekle 2012; Escorcia, 2015) on learning writing skills.

The conceptions which students hold could be changed through continuing support, follow-up and constructive feedback and learning oriented assessment. These make students effective in their writing skills by engaging more in different activities. According to Tuan, Chin \& Shieh (2005, p.641), "when students perceived that they are capable, and they think the conceptual change tasks are worthwhile to participate in and their learning goal is to gain competence, then students will be willing to make a sustained effort and be engaged in making conceptual change".

Currently, writing assessment and learners conceptions have been the focus of researchers such as (Anderson \& Mohrweis, 2008; Lovorn \& Rezaei, 2011; Li \& Lindsey, 2015; Trace, Meier, Janssen, 2016). However, the mentioned researchers did not address interactive, dynamic assessment and the effects of the assessment technique on students' conceptions.

Accordingly, this research concentrated on assessment which helps students learning, which gives a chance to teachers' continuous support and feedback and which makes students in a part of assessment and learning in dynamic assessment criteria. In addition, the research also discovered how dynamic criteria mapping assessment could improve learners' conceptions towards learning writing skills and participating in writing assessment.

\subsection{Literature Review}

\subsubsection{Dynamic Criteria Mapping Assessment}

Dynamic assessment idea was practiced mainly by Feuerstein and Vygotsky with the main notion of zon of proximity development (Xiaoxiao \& Yan, 2010). It is a strategy which is implemented through teachers help and mediation to develop students learning and to understand the potential for the development in learning (Alavi \& Taghizadeh, 2014).

Likewise, dynamic criteria mapping assessment (DCMA) is an assessment and learning approach which was introduced by Broad (2003) and developed with the notion of Vygotsky, zonal proximity development to maximize students learning in writing skills. It is with the assumption that learners progress their learning and acquire the require skill through assisting and mentoring by their adult peers and teachers (Poehner, 2005). Researchers (e.g. Shrestha \& Coffin, 2012; Christmas, Kudzai \& Josiah, 2012; Chanyalew \& Abiy, 2015) explained that learners develop their learning and understand the concept through adult guidance and mediate by capable peers and teachers. Similarly in dynamic assessment approach, students are mediated by their peers and the teacher, and students able to engage in every assessment procedures. In addition, it is implemented continuously with frequent feedback, interactive evaluation, and dynamic criteria. Broad (2003) recommended that instructors prepare dynamic criteria which help them tell the truth about what teachers believe, teach and value in evaluating 
students text. Sills (2016, p. 3) also claimed that the "writing assessment articulates values about what constitute good writing."

Furthermore, the teacher who uses the approach prepares the dynamic criteria by assuming learners language proficiency, course and program objectives, language policy and what they value in their context. According to Zepernick (nd, p. 137), "DCMA privileges local control in every aspect of the assessment process, celebrates the complexity and diversity of features that might represent good writing in any given context and honors the rhetorical process of negotiating local values."

In addition, West-Puckett (2016) argued it is locally responsive assessment which is designed through engagement of all teachers and all students in active, participatory and critical negotiation of assessment paradigms. Johnson and Schuck (2014) asserted that the assessment approach has been successfully used in writing programs to clarify the rhetorical values at play in the classroom and to engage teachers and learners in dialogue concerning how written works are assessed.

Moreover, it also provides the practitioners with a means of continuous evaluation and more reliable means of assessment, (Aghaebrahimian, et al. 2014). It follows a ground-up approach and provides an opportunity to restructure conversation about learning (Broad, et al. 2009; Breideband, 2016).

\subsubsection{Students Conceptions on Teaching/Learning Writing Skills}

Conceptions on learning and assessment refer to the personal beliefs and assumptions people have about their own learning and assessment (Steketee, 1996). As Steketee (1996) cited in Van Rossum and Schenk (1984) stated that conceptions are subjective statements which incorporate the assumptions, rules and conventions that influence the way individuals perceive knowledge as well as the way they approach learning task.

Researchers (Mclean, 2001; Brown \& Hirschfeld, 2008; Alamdarloo, Moradi \& Dehshiri, 2013; Escorcia, 2015) argue that conceptions that students have greatly impacts their academic achievement and motivation. Pajares, (1992) and Thomson (1992) also assert that teachers' beliefs of teaching and learning curricula influence strongly how they teach and how students learn and achieve.

Hence, learners' conceptions could be changed through proper mediation between teachers and students, and learners cognition which is originated shaped through cultural and social interaction process (Watson -Gegeo, 2004; Lantolf \& Thorne, 2006 as cited in Isavi 2012).

Hence, this research attempted to answer the following research questions.

1. Is there a significant difference in students writing skills development between students who are assessed through dynamic criteria mapping assessment and students who are assessed through conventional approach?

2. Is there a significance difference in students writing development among the different types of assessments?

3. What is the effect of dynamic criteria mapping assessment on students' conceptions towards learning and assessing writing skills?

\section{METHOD}

\subsection{Research Design}

The purpose of this research was to explore the effects of dynamic criteria mapping assessment to students writing development. It also endeavored to investigate the assessment approach on students' conceptions towards learning and assessing in writing skills. Thus, the 
researcher employed pretest and post-tests techniques to examine their writing skills improvement. Hence, the research was designed through time series quasi experimental research design.

\subsection{Population and Sample}

The participants of the study were software engineering first year students in the 2016/2017 academic year who were taking basic writing skill course. Multistage sampling technique was employed to choose one section and one department from a total of 29 sections first year students and 14 departments of Bahir Dar Institute of Technology, Bahir Dar University.

Thus, the researcher passed four procedures to determine the study population. First, computing faculty was selected among five faculties (mechanical and industrial engineering, electrical and computer engineering, civil and water resources engineering, chemical and food engineering and computing technology) through systematic sampling technique. Second, of the selected faculty software students were chosen among computer science, information system and information technology departments. Finally, first year students in stated academic year were selected purposively since they were taking basic writing course.

Hence, all population (63 students) which were assigned in the department participated in the study. From these populations, 31 students were assigned to control group and the other 32 students were in experimental group, and the researcher believed that one section with 63 number of population were manageable to give constructive feedback and to follow up their learning progress.

Moreover, the selected subjects were supposed to take two English courses in the 2016/2017 academic year; in the first semester they took communicative English course and in the second semester basic writing skills. Though there is no clear evidence, the participants are believed they are intermediate language users which they can understand main ideas on familiar points and frequent expressions.

\subsection{Data Gathering Instruments}

Pre and Post-test, questionnaire and focus group discussions were used as instruments of the study. Tests were designed to explore students writing improvement within the time series, and focus group discussion and questionnaire were employed to explore students' conceptions on teaching writing and assessment of writing skills.

The questionnaire was adopted from (Abiy, 2005; Neibling, 2014). It includes 14 close ended items which were developed on a five likert scale (strongly agree, agree, undecided, disagree and strongly disagree). The expected mean determined for the one sample t-test was the middle value 3; hence, a mean value above 3 was considered as significant.

Besides, focus group discussions were carried out, so the researcher prepared checklist with 6 themes, and the themes were what students perceived learning writing skills as technology student, how students found the assessment strategies which we used, students' feedback style preferences, students understanding on dynamic criteria assessment and what students want to focus while they write paragraph and essay.

\subsection{Data Collection Procedures}

The procedure of the study was based on the principles of social constructivist, zonal proximity development point of view. After the samples selected, the researcher delivered basic writing courses for one semester for both control and experiment groups, and in each content, instructor assessed frequently and mediated in each activities. 
The experiment and control groups were assessed different writing discourses. Particularly, the control group wrote six (four paragraphs and two essays) discourses and they did not get peer or teacher feedbacks. Whereas, the experimental group wrote six discourses and they get frequent support from both peers and the teachers based on the criteria prepared by the teacher and the students.

The criteria were focused on sentences structure, logical arguments, cohesive devices, developing unified texts, mechanical aspects and syntax. Both groups were assessed within different time intervals, and instruction and assessment for the two groups were carried out for three months simultaneously. However, for this research purpose four paragraphs (one pretest and three post-tests) which were written by students were taken in to consideration.

Moreover, students' questionnaire and focus group discussion checklist were passed with two validation procedures. Firstly, they were reviewed by $\mathrm{PhD}$ students and colleagues at Bahir Dar University. Then, the checklist and the questionnaire were revised and administered to the target population. Finally, it was checked through Cronbach's Alpha and its reliability found as .750.

\subsection{Data Analysis}

Data gathered from the tests and the questionnaires were analyzed using SPSS version 20. Thus, independent sample t-test, descriptive statistics, repeated measure analysis of variances (ANOVA) and one sample t-test were used. Hence, independent sample test was used to examine the statistical difference between the control and the experimental group, and repeated measure ANOVA was used to determine the time series statistical difference among the tests of the groups.

Moreover, descriptive statistics was employed to identify which writing elements contribute more for this difference. In addition, one sample t-test was also employed to determine the level of students' conception towards students learning writing skills and assessing writing skills. The focus group discussion and the quantitative data were analyzed through concurrent mixed method which quantitative and qualitative data were analyzed thematically.

\section{FINDINGS}

\subsection{Students Writing Skills Development}

According to Ismail (2011) the purpose of learning writing skills is to be able to communicate through writing in real life and academic situations. In the study participants wrote paragraphs and essays before and after intervention. Hence, to observe the difference and participants writing skills improvement of the two groups, the independent t-test was run. The statistical difference of the two groups are summarized in Table 1 below.

The table illustrates that there was statistically significance difference between the control and the experiment group which $\mathrm{t}(61)=6.087, \mathrm{p}<0.05$, and the statistical mean of the experiment group was 10.73 , but the control group mean was 8.39 which indicated the experimental group improved their writing skills. Hence, students who were assessed through dynamic criteria assessment improved their writing skills. Students who assessed through dynamic criteria have changed their academic writing results as well as their writing skills. Graham (2008) mentioned that since writing is a complex skill, students require considerable effort and time to use. 
Table 1. statistical difference between the control and the experimental group

\begin{tabular}{|c|c|c|c|c|c|c|c|}
\hline & & \multicolumn{2}{|c|}{$\begin{array}{c}\text { Levene's Test for } \\
\text { Equality of Variances }\end{array}$} & \multicolumn{4}{|c|}{ t-test for Equality of Means } \\
\hline & & $\mathrm{F}$ & Sig. & $\mathrm{t}$ & $\mathrm{df}$ & $\begin{array}{c}\text { Sig. } \\
\text { (2-tailed) }\end{array}$ & $\begin{array}{c}\text { Mean } \\
\text { Difference }\end{array}$ \\
\hline \multirow[t]{2}{*}{ Post test 3} & $\begin{array}{l}\text { Equal variances } \\
\text { assumed }\end{array}$ & 2.331 & .132 & -6.087 & 61 & .000 & -2.347 \\
\hline & $\begin{array}{l}\text { Equal variances } \\
\text { not assumed }\end{array}$ & & & -6.115 & 57.248 & .000 & -2.347 \\
\hline
\end{tabular}

Furthermore, descriptive statistics was run to observe the writing features the students improved. Thus, they abled to develop unified and coherent texts (1.278 in pretest and 2.087 in posttests) and usage of cohesive devises (.976 mean in pre -test and 1.833 in post -test), and the least students writing skills improvements were observed in using explaining ideas logically and using persuasive ideas in their paragraphs (1.266 mean in pre- test and 1.857 in post -test). Finally, they have moderate improvement in sentences structure, proper use of capitalization and punctuation marks in both pre and post tests.

In this study the dynamic mapping assessment helped learners to develop unified paragraph and essay, to use appropriate transitional markers and to improve a text with correct sentences structure, punctuation and other mechanical aspects. As a result, based on what the teacher and students valued and included in the assessment as criteria, they improved their writing skills.

\subsection{Analysis of the Time Series Progress of Students Writing}

Moreover, the time series progresses of students writing improvement were observed through repeated measure ANOVA. As it is indicated in Table 2, dynamic criteria mapping assessment has improved students writing skills;

Table 2. Students' writing skill improvement in paragraph, Tests of within subjects effects

\begin{tabular}{lllllll}
\hline Source & & $\begin{array}{l}\text { Type III Sum of } \\
\text { Squares }\end{array}$ & df & $\begin{array}{l}\text { Mean } \\
\text { Square }\end{array}$ & F & Sig. \\
\hline factor1 & Sphericity Assumed & 634.508 & 3 & 211.503 & 189.139 & .000 \\
& Greenhouse-Geisser & 634.508 & 2.350 & 269.947 & 189.139 & .000 \\
& Huynh-Feldt & 634.508 & 2.449 & 259.089 & 189.139 & .000 \\
& Lower-bound & 634.508 & 1.000 & 634.508 & 189.139 & .000 \\
\hline
\end{tabular}

In addition, there was statistically significance difference among tests (pretest, post test1, post test 2 and post test 3 ) which $\mathrm{F}(3)=189.139, \mathrm{P}<0.05$ and indicates that students improve their writing skills with simultaneous intervention. The estimated margin mean indicate that the control group has a mean value 5.2, 6.2, 7.13, 8.0 in pre-test, posttest 1 , post- test 2 and post -test 3 respectively, but the experimental group means were observed 5.0, 6.00, 8.00 and 9.77 in pre- test, post 1 , post test 2 and post test 3 respectively. This also indicates students in both experimental and the control group improved their writing skills even the mean margin is different.

\subsection{Students Conceptions towards Teaching Writing skills}

Students' conceptions towards teaching and assessing writing skills were also investigated by questionnaire and focus group discussion. The purpose of the conception assessment was to check if students have changed their understanding about learning writing skills and assessing writing after the intervention. 
Table 3. Students' conceptions towards learning writing skills

\begin{tabular}{lccccc}
\hline & $\mathrm{t}$ & $\mathrm{df}$ & $\begin{array}{c}\text { Sig. } \\
(2 \text {-tailed })\end{array}$ & $\begin{array}{c}\text { Mean } \\
\text { Difference }\end{array}$ \\
\hline Class room practices of teaching writing skills & 18.042 & 33 & .000 & 1.13072 \\
\hline
\end{tabular}

As it is explained in the Table 3, students were interested to participate in learning writing skills activities $\mathrm{t}(33)=18.04, \mathrm{P}<.0 .05)$. This indicated that students have positive conceptions and they are very much motivated to participate in learning writing skills and participated in writing activities.

As a result, continuing support of learners and mediation among students helped them to improve their writing skills and to engage in activities. Besides, during focus group discussion students agreed that they have changed their perceptions toward improving and engaging in writing skills. They also find out that they could improve their writing skills, if they practiced well, and majority of the students agreed that they focused on their ideas without much worried about their mechanical errors and they believed that engaging in writing activities help them to use the skills in professional and academic writing.

\subsection{Students Conceptions towards Writing Assessment}

As it can be seen in the Table 4, learners have good understanding towards writing assessment $\mathrm{t}(33)=18.4, \mathrm{p}<0.05$. Hence the data showed that students changed their understanding while they were working with their peers and their teacher, and their conceptions towards participating in peer feedback and accepting teacher feedback during the lesson were improved. Students believed that continuous peer feedback and teacher feedback could help them to develop their writing skills.

Table 4. Students' conceptions towards writing assessment

\begin{tabular}{lcccc}
\hline & $\mathrm{t}$ & $\mathrm{df}$ & $\begin{array}{c}\text { Sig. } \\
(2 \text {-tailed })\end{array}$ & $\begin{array}{c}\text { Mean } \\
\text { Difference }\end{array}$ \\
\hline Students conceptions towards writing assessment & 18.448 & 33 & .000 & 1.47941 \\
\hline
\end{tabular}

In contrast, during focus group discussion, some students explained that they did not think peer feedback help them to improve their writing, and they highly attached to teachers feedback. They also believed that the teacher feedback could show them their gaps more than their peers' feedback. Furthermore, the students agreed on the assessment criteria that the teacher and the students set during writing assessment, and they stated that the class room assessments have impact in their writing development. Lastly, they thought that the criteria that we set told them how much they learnt and the various criteria helped them to see various features of writing.

\section{DISCUSSION}

Dynamic criteria mapping assessment which was used as an approach in this research encompasses extensive activity, collective feedback and interaction. The ultimate goal of teaching writing is effective written communication (Seifoori, Mozaheb \& Beigi, 2012), and this research proved that dynamic criteria mapping assessment is an effective strategy to improve students' written communication.

The students' paragraph and essay had poor introduction in the pre -test sessions with no clear topic sentences and thesis statement, and various unrelated and incoherent ideas were observed in the paragraphs and essays, but as Johnson and Schuck (2014) and West-Puckett 
(2016) mentioned, dynamic characteristic assessment impacted students'learning and they gain better understanding of how writing is learned, practiced and valued. Hence, they abled to construct paragraphs and essays with clear topic sentences and thesis statements and with related and coherent supportive details. Aghaebrahimian, et al. (2014) reported the similar finding which the approach improves students writing skills.

Likewise, the zone of proximity development which is the main characteristics of the dynamic assessment approach (Aghaebrahimian, et al. 2014; Nazari, 2017) is also confirmed by (Isavi, 2012; Marzec-Stawiarska, 2016) as an effective strategy to mediate students writing skills, and feedback strategies (self, peer and teacher) are also effective (Diab, 2016) to scaffold their learning even if students prefer to receive feedback from their teachers. However, Diab (2016) recommended that since self and peer feedback are helpful to reduce students' error significantly, teachers should train them how to get and give feedback, and Yu and Lee (2016) also confirmed that peer feedback strategies help learners to improve learners.

In addition, the research showed students' conceptions changed through participatory and dynamic criteria assessment strategy, and this also improved students enegagment in learning and particepating in different writing activities. Researchers such as (Temesgen, 2013; Krawczyk, 2001) stated that students are motivated to engage if they have positive cognition on writing skills. Carless (2007) also asserted assessments which promote the kind of learning, involvement of students in the assessment process and feedback promotes students engagement and action.

\section{CONCLUSION}

The purpose of this research was to explore the effects of dynamic criteria mapping assessment towards students' writing development and students' conceptions towards writing assessment and learning writing skills. The findings indicated that the assessment contributed for the improvement of students' writing development. Specifically, students develop mechanical aspects like spelling, grammar, punctuation and cohesion (using grammatical elements like connectives, substitution, association and conjunctions).

Furthermore, according to the data, students have changed their conceptions towards learning writing skills and writing assessment. They believed teaching writing contributed for their academic and professional purposes. Hence, students, teachers and other practitioners should work together to enhance students' writing skills, and learning oriented assessment like dynamic criteria mapping assessment can be an alternative assessment technique to develop students' writing skills and to chnage thier concptions.

\section{ORCID}

Amare Tesfie Birhan (D) http://orcid.org/0000-0002-8764-8592

\section{REFERENCES}

Abiy Y. (2005) Effects of Teacher Mediation on students' conceptions and Approaches of reading. Unpublished $\mathrm{PhD}$ dissertation. Addis Ababa University.

Abiy Y. (2013). High school English teachers' and students' perceptions, attitudes and actual practices of continuous assessment. Global Journal of Teacher Education. 1(1), 112-121.

Alamdarloo, G.H., Moradi, S., \& Dehshiri, G.R. (2013). The relationship between students' conceptions of learning and their academic achievement, Psychology, 4 (1), 44-49.

Alavi, S.M., \& Taghizadeh, M. (2014). Dynamic assessment of writing: The impact of implicit/explicit mediations on L2 learners' internalization of writing skills and strategies. Educational assessment, 19 (1), 1-16. 
Aghaebrahimian, A., Rahimirad, M., Ahmadi, A., \& Alamdari, J. (2014). Dynamic Assessment of writing skill in Advanced EFL Iranian Learners: International Conference on Current trends in ELT.

Amare T. (2017). Teachers' Cognition on process genre approach and practices of teaching writing skills in EFL context. English for specific purposes world, 54 (19), 1-17.

Anderson, J.S., \& Mohrweis, L.C. (2008). Using rubrics to assess accounting students' writing, oral presentations and Ethics skills. American Journal of Business Education, 1 (2), 8594.

Angelo, T.A., \& Cross, K.P. (1993). Classroom assessment techniques: A handbook for college teachers. San Francisco: Jossey-Bass.

Beason, L. (2005). Review of what we really value: beyond rubrics in teaching and assessing writing: Council of writing program administration.

Breland, H. M., (1996). Writing Skill Assessment Problems and Prospects. Policy information center. Princeton, Educational Testing service.

Breland, H.M., (1983). The direct assessment of writing skill: A measurement review, College Board report, No. 83-6. Retrieved on October 20, 2017 from https://research.collegeboard.org/sites/default/files/publications/2012/7/researchreport1983-6-direct-assessment-writing-measurement.pdf

Breideband, T. (2016). Alternative Assessment criteria, but how? George State University Student Innovation. Retrieved on July, 17, 2017 from http://sites.gsu.edu/innovation/2016/02/01/alternative-assessment-criteria-but-how/.

Brindley, G. (2001). Assessment. In R. Carter \& D. Nunan (eds.), the Cambridge Guide to Teaching English to Speakers of Other Languages. Cambridge: Cambridge University Press, pp.137-143.

Broad, B., Adler-Kassner, L., Alford, B., Detweiler, J. Estrem, H., Harrington, S., McBride, M., Stalions, E., \& Weeden, S. (2009). Organic writing assessment: Dynamic criteria mapping in action. Utah, Utah state university press.

Broad, B. (2003). What we really value: Beyond Rubrics in Teaching and Assessing writing. Utah. Utah state university press.

Brown, G.T. (2004). Teachers' Conceptions of assessment: implications for policy and professional development. Assessment in education. 11(3), 301-318. DOI: 10.1080/0969594042000304609.

Brown, G.T.L. \& Hirschfeld, G.H.F. (2008). Students' conceptions of assessment: Links to outcomes. Assessment in Education: principles, policy and practice. 15 (1), 3-17.

Carless, D. (2007). Learning-oriented assessment: conceptual bases and practical implications. Innovations in education and teaching international, 44 (1), 57-66.

CERI (2008). Assessment for learning- the case for formative assessment, retrieved on June 20, 2017 from www.oecd.org/site/educeri21st/40600533.pdf.

Chanyalew E. \& Abiy Y. (2015). Effects of teacher scaffolding on students reading comprehension. Science, Technology and Arts Research Journal, 4 (2), 263-271.

Christmas, D., Kudzai, C., \& Josiah, M. (2012). Vygotsky's Zonal Proximity Development Theory: what are its implications for Mathematical teaching? Greener Journal of social sciences, 3 (7), 371-377.

Crusan, D., Plakans, L., \& Gebril, A. (2016). Writing assessment literacy: Surveying second language teachers' knowledge, beliefs and practices. Assessing writing, 28, 43-56.

Diab, N.M. (2016). A comparison of peer, teacher and self-feedback on the reduction of language errors in student essay, system, 57, 55-65. http://dx.doi.org/10.1016/j.system.2015.12.014. 
Escorcia, D. (2015). Teaching and assessing writing skills at university level: a comparison of practices in French and Colombian universities, Educational Research, 57, (3), 254-271.

Freeman, D. \& Richards, J. (1993). Conceptions of teaching and the education of second language teachers. TESOL Quarterly, 27(2), 193-216.

Fulcher, G. \& Davidson, F. (2007). Language Testing and Assessment. London: Routledge, Taylor and Francis group.

Graham, S. (2008). Effective writing instruction for all students, Renaissance learning.

Hailay T. (2017). Investigating the practices of assessment methods in Amharic language writing skill context. The case of selected higher education in Ethiopia. Educational Research and Reviews, 12(8), 488-493.

Hyland, K. (2003). Second Language writing. Cambridge. Cambridge University press.

Isavi, E. (2012). The effects of dynamic assessment on Iranian L2 writing performance. Retrieved on October 25, 2017 from https://files.eric.ed.gov/fulltext/ED530902.pdf.

Ismail, S. A. A. (2011). Exploring students' perceptions of ESL writing. English Language Teaching, 4(2), 73-83.

Janssen, G., Meier, V., \& Trace, J. (2015). Building a better rubric: Mixed methods rubric revision. Assessing writing. 26, 51-66.

Johnson, K.E. \& Schuck, C. (2014). Using dynamic criteria mapping to improve curriculum alignment across institutions. Retrieved on July, 18, 2017 from http://cop.hlcommission.org/Assessment/johnson.html

Kim, J. \& Kim, Y. (2005). Teaching Korean university writing class: Balancing the process and the genre approach. Asian EFL Journal. 7 (2). 1-15.

Kim, A.H., \& Kim, H.J. (2017). The effectiveness of instructor feedback for learning-oriented language assessment: using an integrated reading-to write task for English for academic purposes. Assessing writing. 32, 57-71.

Krawczyk, J. (2001). Writing attitudes: Determining the effect of a community of learners project on the attitudes of composing students, MA thesis, Oklahoma state University.

Li, J., \& Lindsey, P. (2015). Understanding variations between student and teacher application of rubrics. Assessing writing, 26, 67-79.

Lovorn, M. G., \& Rezaei, A. R. (2011). Assessing the assessment: Rubrics training for preservice and In-service teachers. Practical assessment, research and evaluation, 16 (16).

Marzec-Stawiarska, M. (2016). The influence of summary writing on the development of reading skills in a foreign language, system, 59, 90-99.

McCune, V. (2004). Development of first year students' conceptions of essay writing. Higher Education, 47, 257-282.

McLean, M. (2001). Can we relate conceptions of learning to student academic achievement? Teaching in higher education, 6 (3), 399-413. DOI: 10.1080/13562510120061241

Ministry of education (2013). English department harmonized curriculum, unpublished curriculum, Addis Ababa.

Nazari, A. (2017). Dynamic assessment in higher education English classes: a lecturer perspective. The Journal of Language Teaching and Learning, 7(1), 100-118.

Neibling, J.L. (2014). Teachers' Conceptions Towards Type of Assessment: Grade Level and State Tested Content Area. MA thesis, Kansas University.

Pajares, F. (1992). Teachers' beliefs and educational research: Cleaning up a messy construct. Review of Educational Research, 62(3), 307-332.

Poehner, E. (2005). Dynamic assessment of oral proficiency among advanced L2 learners of French. Pennsylvania State University. 
Rezaei, A.R.,\& Lovorn, M. (2010). Reliability and Validity of rubrics for assessment through writing. Assessing writing, 15(1), 18-39.

Richards, J. (1990). The Language Teaching Matrix. Cambridge: Cambridge University press.

Seifoori, Z., Mozaheb, M.A., \& Beigi, A.B. (2012). A profile of an effective EFL writing Teachers (A technology-based approach). English Language Teaching, 5 (5), 107-117.

Shrestha, P., \& Coffin, C. (2012). Dynamic assessment, tutor mediation, and academic writing development. Assessing writing, 17 (1), 55-70.

Sills, E. (2016). Multimodal assessment as disciplinary sense making: Beyond rubrics to framework. The journal of writing assessment, 9 (2). Retrieved on October 27, 2017 from http://journalofwritingassessment.org/article.php?article $=109$

Steketee, C.N. (1996). Conceptions of learning held by students in the lower, middle and upper grades of primary school. Retrieved on September 14, 2017 from http://ro.edu.au/theses_hons/677

Tabar, M., \& Davoudi, M. (2015). The Effects of computerized Dynamic Assessment of L2 Writing on Iranian EFL Learner's Writing Development. International Journal of Linguistics and Communication. 3 (2), 176-186.

Tekle F., Endalfer M., \& Ebabu T. (2012), a descriptive survey on Teachers' perception of EFL writing and their practice of teaching writing: Preparatory schools in Jimma zone in focus. Ethiopian journal of education and science, 1 (1), 29-52.

Temesgen E. (2013), Factors that affect learners' motivations towards the writing skills: the case of grade twelve students in Wachemo preparatory school, Hosanna, MA thesis.

Thompson, A. G. (1992). Teachers' beliefs and conceptions: A synthesis of the research: In D. A. Grouws (Ed.), Handbook of research on mathematics teaching and learning (pp. 127146). New York: Macmillan.

Trace, J., Meier, V., \& Janssen, G. (2016). “I can see that": Developing shared rubrics category interpretations through score negotiation. Assessing writing, 30, 32-43.

Tuan, H.L., Chin, C.C., \& Shieh, S.H. (2005). The development of a questionnaire to measure students' motivation towards science learning. International Journal of Science and Education. 27 (6), 639-654.

Vygotsky, S. (1978). Mind in Society: The Development of Higher psychology Processes: Cambridge: Harvard University Press.

West-Puckett, S. (2016). Making classroom writing assessment more visible, equitable and portable through digital badging. College English, 79 (2), 127-151.

Xiaoxiao, L., \&Yan, L. (2010). A case study of Dynamic assessment in EFL process writing. Chinese Journal of Applied Linguistics, 33 (1), 24-40.

$\mathrm{Yu}, \mathrm{S} .$, \& Lee, I. (2016). Exploring Chinese students' strategy to use in a cooperative peer feedback writing group, system, 58, 1-11.

Yiheyis S., \& Getachew S. (2014). The implementation of continuous assessment in writing classes of Jimma College of teacher education. Ethiopia Journal of Education and science. 10 (1), 109-135.

Zepernick, J.S. (nd). Reviewed Organic writing assessment: Dynamic criteria mapping in action, by Broad, B., Adler-Kassner, L., Alford, B., Detweiler, J., Estrem, H., Harrington, S., McBrdide, M., Stalions, E., \& Weeden, S. (2009). Longon: Utah State UP.

Zoghi, M., \& Ma lmeer, E. (2013). The effect of Dynamic assessment on EFL learners' intrinsic motivation. Journal of Language Teaching and Research, 4(3), 584-591. 